\title{
THE ISSUES OF MEASURING THE EXTERIOR AND INTERIOR NOISE OF ROAD VEHICLES
}

Nowadays, within the issues of road vehicles operation, we place great emphasis especially on the most important operating characteristics such as fuel consumption, exhaust emissions as well as performance indicators. However, in the field of driving comfort, a noise inside the vehicle, affecting its crew, represents an important aspect as well. The paper analyzes the interior and exterior vehicle noise, methods of its detection and practical research measurement indicating the rate of interior vehicle noise during various traffic conditions.

Keywords: Exterior noise, interior noise, road vehicle, measurement, vehicle operation, traffic.

\section{Introduction}

Noise represents a special position among several negative environmental factors and unfavorable, even damaging, human effects. Nowadays, risk evaluation of noise exposure represents extremely urgent issue due to the enormous increase in acoustic energy in the environment. Road transport has the largest share in generating the traffic noise. Thus, road traffic noise is one of the fundamental reasons considered within the contact human - transport [1 and 2].

Below mentioned basic terms define and directly specify the noise as an objectionable environmental sound causing even annoying feeling that has generally an unfavorable effect [2 - 4]: (1) Noise - every unwanted, intrusive, annoying or harmful sound that causes the biological reaction of humans and animals; (2) The Noise Level $(\boldsymbol{L A})$ in $\mathbf{d B}$ - the level of acoustic pressure weighted using the weighting filter $\boldsymbol{A}$; (3) The Percentage Noise Level - the sound level with A weighting obtained during the weighing time function $\boldsymbol{F}$ (fast), exceeded in percentage of the total evaluation period. Denotation - $L N$ (e.g. L1,10,50,90,99); (4) The Equivalent Noise Level $\left(\boldsymbol{L} \boldsymbol{A}_{e q}\right)$ in $\mathbf{d B}$ - is consistent data that is used to describe the sound course with a varying sound level which includes the road traffic noise as well. It is calculated as an acoustic pressure which is energetically equivalent to the long-term effect of intermittent noise or noise with a varying sound level.

\section{Legislation relating to the field of measuring the road vehicles noise}

In the beginning of the legislative framework analysis relating to the issue of road vehicles noise, it is important to mention the basic divisions of road vehicles noise which are regulated by different legislative rules either in the field of road vehicles approval, or the operation itself [5].

The field of road vehicles noise [4 and 5]: (1) inside the vehicle - interior noise; (2) noise outside the vehicle - exterior noise.

In terms of the road vehicle operation, it is possible to measure the interior and exterior noise [5]: (1) standing vehicle (idle engine speed or increased engine speed); (2) vehicle in motion (different vehicle speeds, acceleration).

The reason for measuring the road vehicle noise [ 3 and 5]: (1) road vehicles approval; (2) tests in operation; (3) other (research-development testing, etc.).

The basic legislative frameworks contain various combinations of these types of tests. For example, during the type-approval of road vehicles, the exterior noise of the standing vehicle as well as the vehicle in motion is measured. On the contrary, during the technical control of road vehicle in its operation, technician, in the technical inspection station (TIS), only measures the vehicle exterior noise standing at increased engine speed (revolutions per minute).

\footnotetext{
* ${ }^{1}$ Branislav Sarkan, ${ }^{2}$ Ondrej Stopka, ${ }^{3}$ Chenguang Li

${ }^{1}$ Department of Road and Urban Transport, Faculty of Operation and Economics of Transport and Communications, University of Zilina, Slovakia ${ }^{2}$ Department of Transport and Logistics, Faculty of Technology, Institute of Technology and Business in Ceske Budejovice, Czech Republic ${ }^{3}$ School of Economics and Management, North China University of Technology, Beijing, China

E-mail: branislav.sarkan@fpedas.uniza.sk
} 


\subsection{Council Directive 70/157/EEC}

Council Directive 70/157/EEC of 6 February 1970 on the approximation of the laws of the Member States relating to the permissible sound level and the exhaust system of motor vehicles. Since its adoption, this Directive was repeatedly substantially amended. The latest reduction in sound level limits for motor vehicles in 1995 did not bring the desired effect. Studies have shown that a test method used by the Directive, did not reflect the true nature of driving in urban traffic any longer. As pointed out in the Green Paper on a future policy on noise since November 4, 1996, in the test method, the contribution of a tire rolling noise to the total noise emission was underestimated. This directive refers to the Regulation of the United Nations Economic Commission for Europe (UNECE) no. 51 on noise emissions, setting out a test method for noise emissions, and the Regulation of the UNECE no. 59 on provisions concerning the approval of replacement silencing systems [6 - 8].

According to this directive, the following vehicles are controlled [6 - 8]:

- standing vehicle - measurement is carried out according to this directive requirements (noise meter microphone placement) at different engine speeds. The result is logged to the vehicle registration certificate and is the basis for the vehicle test in operation.

- vehicle in motion - measurement is carried out according to this directive specific requirements. The result of this test must meet the prescribed limits defined by this directive for specific categories of road vehicles. According to this directive, the measured noise values of the standing vehicle and vehicle in motion are logged into the vehicle registration certificate as well.

\subsection{Regulation of the European Parliament and of the Council (EU) no. 540/2014}

Regulation of the European Parliament and of the Council (EU) no. 540/2014 of 16 April 2014 on the sound level of motor vehicles and of replacement silencing systems, and amending the Directive 2007/46/EC and repealing the Directive 70/157/EEC. Thus, this regulation should introduce a test method that is different from the method set out in the Directive 70/157/EEC. The new method should be based on the test method published in 2007 by the UNECE Working Party on Noise (GRB) and into which the version of the ISO standard 362 in 2007 has been incorporated. The results of monitoring both the old and the new test methods were submitted to the Commission. This regulation brought a tightening noise limits for the type-approval of road vehicles. The process of gradual reduction of environmental burden by the road vehicles operation is planned in the various phases up to 2026 [7 and 8].

\section{Practical measurements}

Practical measurements were carried out on a selected group of road passenger vehicles with the parameters defined in Table 1. For those vehicles, permitted or measured levels of exterior noise of a standing vehicle and vehicle in motion are indicated in the vehicle registration certificate according to the Council Directive 70/157/EEC [6, 8 and 9].

\subsection{Exterior noise of the vehicle in motion}

For a selected group of vehicles, exterior noise level was measured according to the "Methodology" defined in the Council Directive 70/157/EEC. 3 measurements for each

Used vehicles during the practical measurement

Table 1

\begin{tabular}{|c|c|c|c|c|c|c|c|}
\hline $\begin{array}{c}\text { Vehicle } \\
\text { brand }\end{array}$ & $\begin{array}{c}\text { Trade } \\
\text { name }\end{array}$ & $\begin{array}{c}\text { Engine } \\
\text { capacity } \\
\left(\mathrm{cm}^{3}\right)\end{array}$ & Production year & $\begin{array}{c}\text { Maximum engine } \\
\text { performance } \\
\left(\mathrm{kW} / \mathrm{min}^{-1}\right)\end{array}$ & $\begin{array}{c}\text { Fuel } \\
\text { type }\end{array}$ & $\begin{array}{c}\text { Level of exterior noise of } \\
\text { a standing vehicle } \\
\left(\mathrm{dB} / \mathrm{rpm}^{-1}\right)\end{array}$ & $\begin{array}{c}\text { Level of exterior noise } \\
\text { of a vehicle in motion } \\
(\mathrm{dB})\end{array}$ \\
\hline Skoda & Octavia & 1896 & 2008 & $77 / 4000$ & Diesel & $79 / 3000$ & 69 \\
\hline VW & Passat & 1896 & 1996 & $81 / 4150$ & Diesel & $83 / 3113$ & 72 \\
\hline Renault & Thalia & 1149 & 2007 & $55 / 5500$ & Petrol & $82 / 4125$ & 70 \\
\hline Opel & Zafira & 1995 & 2004 & $74 / 4000$ & Diesel & $77 / 3000$ & 73 \\
\hline Opel & Vectra & 1598 & 1996 & $74 / 6200$ & Petrol & $83 / 4650$ & 73 \\
\hline Mazda & 323 & 1840 & 2000 & $84 / 6000$ & Petrol & $86 / 4500$ & 72 \\
\hline Peugeot & 206 & 1868 & 1998 & $51 / 4600$ & Diesel & $86 / 3450$ & 73 \\
\hline Skoda & Felicia & 1289 & 2001 & $50 / 5000$ & Petrol & $78 / 3750$ & 75 \\
\hline Renault & Clio & 1390 & 1997 & $55 / 5750$ & Petrol & $84 / 4313$ & \\
\hline
\end{tabular}

Source: authors 
Noise emission limits during the test of the vehicle in motion

Table 2

\begin{tabular}{|c|c|c|c|c|c|c|c|c|}
\hline \multirow{3}{*}{ Vehicle } & \multicolumn{6}{|c|}{ Exterior noise of the vehicle in motion } & \multirow{3}{*}{$\begin{array}{l}\text { Methodology } \\
\text { (dB) }\end{array}$} & \multirow{3}{*}{$\begin{array}{l}\text { Difference between the highest } \\
\text { measured value and the } \\
\text { "Methodology“ value }(\mathrm{dB})\end{array}$} \\
\hline & \multicolumn{2}{|c|}{$1^{\text {st }}$ measurement } & \multicolumn{2}{|c|}{$2^{\text {nd }}$ measurement } & \multicolumn{2}{|c|}{$3^{\text {rd }}$ measurement } & & \\
\hline & $\begin{array}{l}\text { Left side } \\
\mathrm{dB}(\mathrm{A})\end{array}$ & $\begin{array}{l}\text { Right side } \\
\text { dB (A) }\end{array}$ & $\begin{array}{l}\text { Left side } \\
\mathrm{dB}(\mathrm{A})\end{array}$ & $\begin{array}{l}\text { Right side } \\
\text { dB (A) }\end{array}$ & $\begin{array}{c}\text { Left side } \\
\mathrm{dB}(\mathrm{A})\end{array}$ & $\begin{array}{c}\text { Right side } \\
\text { dB (A) }\end{array}$ & & \\
\hline $\begin{array}{c}\text { Volkswagen } \\
\text { Passat }\end{array}$ & 72.8 & 72.6 & 72.8 & 72.6 & 71.8 & 72 & 72 & 0.8 \\
\hline Skoda Octavia & 69 & 69.2 & 68 & 68.5 & 68.5 & 68.7 & 69 & 0.2 \\
\hline Renault Thalia & 70 & 69.8 & 70.5 & 70.3 & 71 & 71.2 & 70 & 1.2 \\
\hline Opel Zafira & 72.3 & 72.4 & 72 & 72.1 & 71.8 & 72 & 72 & 0.4 \\
\hline Opel Vectra & 77 & 77.1 & 76.9 & 76.8 & 76.9 & 77 & 73 & 4.1 \\
\hline Mazda 323 & 70.1 & 69,9 & 70.7 & 70.5 & 71 & 69.9 & 73 & -2 \\
\hline Peugeot 206 & 71.5 & 71.9 & 72.9 & 72.6 & 72.3 & 72.4 & 72 & 1.9 \\
\hline Skoda Felicia & 71.9 & 71.9 & 71.8 & 71.7 & 72 & 71.9 & 73 & -1 \\
\hline Renault Clio & 74.5 & 74.4 & 74.9 & 74.8 & 73.5 & 73.7 & 75 & -0.1 \\
\hline
\end{tabular}

Source: authors

vehicle were carried out with a requirement of the noise measuring on the vehicle left and the right side [6,8 and 10].

A microphone must be placed at a distance of $7.5 \mathrm{~m}+/$ $0.2 \mathrm{~m}$ from a reference line of the roadway and $1.2 \mathrm{~m}+/-0.1 \mathrm{~m}$ above the ground. Its axis of maximum sensitivity must be horizontal and perpendicular to the vehicle roadway. When the vehicle front reaches the specific line, the accelerator fully opens as quickly as possible and is held in the fully opened position, until the rear vehicle intersects another specific line. Then, the accelerator closes as quickly as possible [11 - 13]."

The measured values are compared with the "Methodology" and listed in following Table 2.

\subsection{Exterior noise of the standing vehicle}

A microphone is placed at a distance of $0.5 \mathrm{~m} \pm 0.01$ from a reference point of the exhaust pipe and at angle of $45^{\circ}$ $\left( \pm 5^{\circ}\right)$ to the vertical level in which the exhaust flow axis at the exhaust pipe outlet is placed. A microphone must be placed at a reference point, however, no less than $0.2 \mathrm{~m}$ from the ground surface. The microphone reference axis must be placed in a level parallel to the ground surface and must be directed to the reference point at the exhaust pipe outlet [11, 14 and 15].

Noise emission limits during the test of the standing vehicle are listed in following Table 3.

According to the Council Directive $70 / 157 /$ EEC, it is necessary to measure the noise emissions of the standing vehicle for the selected vehicles at engine speed equal to $3 / 4$ of

Noise emission limits during the test of the standing vehicle

Table 3

\begin{tabular}{|c|c|c|c|c|c|c|c|c|}
\hline \multirow{3}{*}{ Vehicle } & \multicolumn{6}{|c|}{ Exterior noise of the vehicle in motion } & \multirow{3}{*}{$\begin{array}{l}\text { Methodology } \\
\text { (dB) }\end{array}$} & \multirow{3}{*}{$\begin{array}{l}\text { Difference between the highest } \\
\text { measured value and the } \\
\text { „Methodology“ value }(\mathrm{dB})\end{array}$} \\
\hline & \multicolumn{2}{|c|}{$1^{\text {st }}$ measurement } & \multicolumn{2}{|c|}{$2^{\text {nd }}$ measurement } & \multicolumn{2}{|c|}{$3^{\text {rd }}$ measurement } & & \\
\hline & $\begin{array}{l}\text { Left side } \\
\mathrm{dB}(\mathrm{A})\end{array}$ & $\begin{array}{l}\text { Right side } \\
\text { dB (A) }\end{array}$ & $\begin{array}{l}\text { Left side } \\
\mathrm{dB}(\mathrm{A})\end{array}$ & $\begin{array}{c}\text { Right side } \\
\text { dB (A) }\end{array}$ & $\begin{array}{c}\text { Left side } \\
\mathrm{dB}(\mathrm{A})\end{array}$ & $\begin{array}{c}\text { Right side } \\
\text { dB (A) }\end{array}$ & & \\
\hline $\begin{array}{c}\text { Volkswagen } \\
\text { Passat }\end{array}$ & 66.8 & 71.6 & 76.4 & 86.5 & 83 & 3.5 & 66.8 & 71.6 \\
\hline Skoda Octavia & 59.8 & 63.3 & 70.5 & 78.7 & 79 & -0.3 & 59.8 & 63.3 \\
\hline Renault Thalia & 54 & 66 & 71 & 81.5 & 82 & -0.5 & 54 & 66 \\
\hline Opel Zafira & 57 & 63.5 & 71.5 & 76.8 & 77 & -0.2 & 57 & 63.5 \\
\hline Opel Vectra & 57 & 65 & 77.3 & 86.5 & 83 & 3.5 & 57 & 65 \\
\hline Mazda 323 & 59.2 & 63.6 & 79 & 85 & 86 & -1 & 59.2 & 63.6 \\
\hline Peugeot 206 & 61.6 & 67.4 & 84 & 93.3 & 86 & 7.3 & 61.6 & 67.4 \\
\hline Skoda Felicia & 65.2 & 67.9 & 70.3 & 77.4 & 78 & -0.6 & 65.2 & 67.9 \\
\hline Renault Clio & 58.9 & 63 & 67.1 & 84.5 & 84 & 0.5 & 58.9 & 63 \\
\hline
\end{tabular}

Source: authors and [6] 
rated engine speed. In this case, the test is extended to noise emission values at idle engine speed and engine speed of 1000 rpm and $2000 \mathrm{rpm}$. The highest noise value exceeding the limit specified by this directive is achieved by Peugeot 206 [11, 14 and 15].

3.3. Comparison of exterior and interior noise of the vehicle in motion

A vehicle comfort level with respect to its noise on the passengers could be evaluated not only through the interior vehicle noise at a point of the driver's right organ of hearing, but also determining the "reduction rate of exterior noise into the vehicle passenger cab" [3, 9 and 16].

The individual measured and recorded values are summarized in Table 4.

Comparison of exterior and interior noise of the vehicle in motion

Table 4

\begin{tabular}{|c|c|c|c|}
\hline Vehicle & $\begin{array}{c}\text { Maximum } \\
\text { exterior noise } \\
(\mathrm{dB})\end{array}$ & $\begin{array}{c}\text { Maximum } \\
\text { interior noise } \\
(\mathrm{dB})\end{array}$ & $\begin{array}{c}\text { Difference } \\
(\mathrm{dB})\end{array}$ \\
\hline Volkswagen Passat & 72.8 & 67.9 & 4.9 \\
\hline Skoda Octavia & 69.2 & 64 & 5.2 \\
\hline Renault Thalia & 71.2 & 83.3 & 12.1 \\
\hline Opel Zafira & 72.4 & 64.6 & 7.8 \\
\hline Opel Vectra & 77.1 & 74.5 & 2.6 \\
\hline Mazda 323 & 71 & 68.6 & 2.4 \\
\hline Peugeot 206 & 72.9 & 68.8 & 4.1 \\
\hline Skoda Felicia & 72 & 67.3 & 4.7 \\
\hline Renault Clio & 74.9 & 63 & 11.9 \\
\hline
\end{tabular}

Source: authors

Diametrically opposed values of the interior noise of Renault Thalia and Renault Clio are quite interesting. Inside the vehicle Renault Thalia, the interior noise level is of 12.1 $\mathrm{db}$ higher compared to the exterior noise produced by this vehicle. As for Renault Clio, the lowest detected value of interior noise level of $63 \mathrm{db}$ is equivalent to the exterior noise reduction by $11.9 \mathrm{~dB}$.

Paradox of the vehicles Renault Thalia, with the high interior noise level, could be caused by [17 and 18]:

- insufficient soundproofing from the engine compartment,

- insufficient soundproofing from the vehicle undercarriage (chassis).

Individual values from the comparison of exterior and interior noise of the vehicle in motion are summarized in Table 3.

\subsection{Comparison of exterior and interior noise of the standing vehicle}

The comparison of the standing vehicle exterior and interior noise at various levels of engine speed (idle engine speed, $1000 \mathrm{rpm}, 2000 \mathrm{rpm}$ and $3 / 4$ of rated engine speed) can be considered as a test with a greater degree of explanatory value.

The measured noise level data can be assessed in two ways [12 and 19]:

- by evaluation of the absolute values,

- by evaluation of the exterior noise reduction (difference, ratio, etc.).

The comparison of exterior and interior noise of the standing vehicle is shown in Table 5.

From the detected noise values summarized in Table 5 , the increase rate of the exterior and interior noise of the standing vehicle can be calculated as well. Evidently, Peugeot 206 is the noisiest vehicle in terms of the interior as well as exterior noise. An enormous noise increase, when increasing

Comparison of exterior and interior noise of the standing vehicle

Table 5

\begin{tabular}{|c|c|c|c|c|c|c|c|c|c|c|c|c|}
\hline \multirow{3}{*}{ Vehicle } & \multicolumn{12}{|c|}{ Noise $(\mathrm{dB})$} \\
\hline & \multicolumn{3}{|c|}{ Idle engine speed } & \multicolumn{3}{|c|}{$1000 \mathrm{rpm}$} & \multicolumn{3}{|c|}{$2000 \mathrm{rpm}$} & \multicolumn{3}{|c|}{$3 / 4$ of rated engine speed } \\
\hline & $\begin{array}{l}\text { Ext. } \\
\text { noise }\end{array}$ & $\begin{array}{l}\text { Int. } \\
\text { noise }\end{array}$ & Difference & $\begin{array}{l}\text { Ext. } \\
\text { noise }\end{array}$ & $\begin{array}{l}\text { Int. } \\
\text { noise }\end{array}$ & Difference & $\begin{array}{l}\text { Ext. } \\
\text { noise }\end{array}$ & $\begin{array}{l}\text { Int. } \\
\text { noise }\end{array}$ & Difference & $\begin{array}{l}\text { Ext. } \\
\text { noise }\end{array}$ & $\begin{array}{l}\text { Int. } \\
\text { noise }\end{array}$ & Difference \\
\hline $\begin{array}{c}\text { Volkswagen } \\
\text { Passat }\end{array}$ & 66.8 & 61.2 & 5.6 & 71.6 & 70 & 1.6 & 76.4 & 72.2 & 4.2 & 86.5 & 74.2 & 12.3 \\
\hline Skoda Octavia & 59.8 & 52.6 & 7.2 & 63.3 & 63.4 & 0.1 & 70.5 & 66.3 & 4.2 & 78.7 & 65 & 13.7 \\
\hline Renault Thalia & 54 & 58 & 4.0 & 66 & 66.3 & 0.3 & 71 & 66.3 & 4.7 & 81.5 & 76 & 5.5 \\
\hline Opel Zafira & 57 & 53.5 & 3.5 & 63.5 & 62.5 & 1.0 & 71.5 & 61 & 10.5 & 76.8 & 63.9 & 12.9 \\
\hline Opel Vectra & 57 & 47.4 & 9.6 & 65 & 65.1 & 0.1 & 77.3 & 71 & 6.3 & 86.5 & 80 & 6.5 \\
\hline Mazda 323 & 59.2 & 52.2 & 7.0 & 63.6 & 55.9 & 7.7 & 79 & 77.2 & 1.8 & 85 & 81 & 4.0 \\
\hline Peugeot 206 & 61.6 & 58.8 & 2.8 & 67.4 & 63.4 & 4.0 & 84 & 78.3 & 5.7 & 93.3 & 91.6 & 1.7 \\
\hline Skoda Felicia & 65.2 & 61.1 & 4.1 & 67.9 & 64.2 & 3.7 & 70.3 & 69.9 & 0,4 & 77.4 & 72.8 & 4.6 \\
\hline Renault Clio & 58.9 & 49.9 & 9.0 & 63 & 61.7 & 1.3 & 67.1 & 60.1 & 6.0 & 84.5 & 79.2 & 5.3 \\
\hline
\end{tabular}

Source: authors 
the engine speed, can be seen as well. On the contrary, Opel Zafira is considered to be the least noisy vehicle based on the performed measurements. At the rated engine speed, it is able to reduce the vehicle interior noise by $12.9 \mathrm{~dB}$ compared to the exterior noise.

\section{Noise measurements in the technical inspection station}

In normal operation of road vehicles, their noise level can be controlled in the technical inspection stations. Exterior noise level of the standing vehicle is measured according to the Methodical instruction No. 77/2011 [20].

Exterior noise level of the standing vehicle is assessed by the inspection technician subjectively, without using a sound level meter. If inspection technician, on the basis of his subjective judgment, cannot clearly assess whether the exterior noise level is not higher than the permissible value, he carries out the particular measurement [6,21 and 22].

The resulting measured data is compared with a reference value. The reference value is determined from the data on the standing vehicle exterior noise level indicated in a given vehicle registration certificate plus a tolerance of $+5 \mathrm{~dB}(\mathrm{~A})$ [22 - 24].

From the analyzed road vehicle group, Peugeot 206 does not meet a prescribed procedure of the inspection. It exceeds the value indicated in a vehicle registration certificate by 7.3 $\mathrm{dB}$. In this case, if the measured exterior noise level value of the standing vehicle is higher than the permissible value, the vehicle is evaluated as "B" (temporarily fit for traffic) during the technical inspection. This means that the vehicle must be returned for performing the technical inspection within 30 days.

\section{Conclusions}

The issues of measuring the noise of road vehicles can be considered broadly comprehensive and highly topical. A lot of experts at international level deal with this field of study. The group known as "GBR" (Working Group on Noise from Road Vehicles), which is part of the World Forum for the Harmonization of Vehicle Regulations (WP.29) - part of the inland transport committee in the European Economic Community, represents an illustrative example [2, 8 and 25].

The processed article reports, inter alia, an overview of the exterior noise of road transport vehicles evaluation which is considered to be a part of the vehicle approval tests. A special attention is paid to the noise inside the vehicle. When purchasing the vehicle, its common a future user has available an amount of data about the required vehicle (performance, fuel consumption, parameters, etc.), however, an important detail regarding the comfort inside the vehicle is not available for him. This parameter is represented by the interior noise affecting the vehicle crew, especially the vehicle driver [26 and 27].

Authors of this paper predict that this issue of measurement and evaluation of vehicle interior noise will be readily available and important criterion concerning the vehicle selection in the future.

\section{Acknowledgement}

This paper has been developed under the support of: National Natural Science Foundation of China (No. 71503011) and Beijing Social Science Foundation of China (No. 16GLC041).

\section{References}

[1] MELO, R. A., PIMENTEL, R. L., LACERDA, D. M., SILVA, W. M.: Applicability of Models to Estimate Traffic Noise for Urban Roads, J. of Environmental Health Science and Engineering, vol. 13, No. 83, 2015, ISSN 2052-336X, DOI: 10.1186/s40201-015-0240-9.

[2] GOGOLA, M., VETERNIK, M.: The Analysis of the Environmental Impact of Road Traffic in City of Martin, Logi - Scientific J. on Transport and Logistics, vol. 7, No. 1, 2016, 49-60, ISSN 1804-3216.

[3] DURCANSKA, D., et al.: Assessment of Roads and Highways Impacts on the Environment - Noise and Imissions from Road Transport (in Slovak), University of Zilina : EDIS, 2002, ISBN 80-8070-029-X.

[4] MARUYAMA, M., KUNO, K., SONE, T.: New Mathematical Model to Estimate Road Traffic Noise in View of the Appearance Rate of Heavy Vehicles, International J. of Acoustics and Vibration, vol. 16, No. 2, 2011, 64-71, ISSN 1027-5851.

[5] JANCZUR, R., WALERIAN, E., CZECHOWICZ, M.: Road Model as a Noise Source, Acta Acustica United with Acustica, vol. 95, No. 1, 2009, 156-167, ISSN 1610-1928, DOI: 10.3813/AAA.918137.

[6] COUNCIL DIRECTIVE 70/157/EEC On the approximation of the laws of the Member States relating to the permissible sound level and the exhaust system of motor vehicles, 1970.

[7] REGULATION OF THE EUROPEAN PARLIAMENT AND OF THE COUNCIL (EU) NO. 540/2014 on the sound level of motor vehicles and of replacement silencing systems, and amending Directive 2007/46/EC and repealing Directive 70/157/EEC, 2014. 
[8] VEHICLE REGULATIONS - TRANSPORT - UNECE. World Forum for the harmonization of vehicle regulations (WP.29), [Electronic source]. [Citation 2016-09-21]. 2016. Accessible via: 〈http://www.unece.org/trans/main/welcwp29.html〉.

[9] VIJAY, R., KORI, C., KUMAR, M., CHAKRABARTI, T., GUPTA, R.: Assessment of Traffic Noise on Highway Passing from Urban Agglomeration, Fluctuation and Noise Letters, vol. 13, No. 4, 2014, ISSN 0219-4775, DOI: 10.1142/ S021947751450031X.

[10] KINDT, P., BERCKMANS, D., DE CONINCK, F., SAS, P., DESMET, W.: Experimental Analysis of the Structure-Borne Tyre/Road Noise Due to Road Discontinuities, Mechanical Systems and Signal Processing, vol. 23, No. 8, 2557-2574, 2009, ISSN 0736-2501, DOI: 10.1016/j.ymssp.2009.04.005.

[11] DISTEFANO, N., LEONARDI, S.: Experimental Investigation of the Effect of Speed Bumps in Sequence on Noise Emission Level from Motor Vehicles, Noise Control Engineering J., vol. 63, No. 6, 2015, 582-597, ISSN 0736-2501.

[12] WENTZEL, R.E., AUBERT, A.: Using a Dynamometer Along with Road Tests to Measure Vehicle Rolling and Wind Noise, Proc. of Noisecon/ASME NCAD-2008 - Noise-Control 2008/Sound Quality Symposium/30th Annual Conference of ASME Noise Control and Acoustics Division, Dearborn, Michigan, 2009, 201-206, ISBN 978-0-7918-4839-5.

[13] BRAND, S., PETRI, M., HAAS, P., KRETTEK, C., HAASPER, C.: Hybrid and Electric Low-Noise Cars Cause an Increase in Traffic Accidents Involving Vulnerable Road Users in Urban Areas, Intern. J. of Injury Control and Safety Promotion, vol. 20, No. 4, 2013, 339-341, ISSN 1745-7300, DOI: 10.1080/17457300.2012.733714.

[14] JU, H., HUANG, X., YU, X.: Influence of Traffic Regulation Factors on Noise in Ordinary Urban Roads, Dongnan Daxue Xuebao (Ziran Kexue Ban)/J. of Southeast University (Natural Science Edition), vol. 44, No. 2, 2014, 420-424, ISSN 1001-0505, DOI: 10.3969/j.issn.1001-0505.2014.02.034.

[15] HEUTSCHI, K., BUHLMANN, E., OERTLI, J.: Options for Reducing Noise From Roads and Railway Lines, Transportation Research Part A: Policy and Practice, vol. 94, 2016, 308-322, ISSN 0965-8564, DOI: 10.1016/j.tra.2016.09.019.

[16] CHEER, J., ELLIOTT, S. J.: The Design and Performance of Feedback Controllers for the Attenuation of Road Noise in Vehicles, Intern. J. of Acoustics and Vibration, vol. 19, No. 3, 2014, 155-164, ISSN 1027-5851.

[17] KUMAR, P., NIGAM, S. P., KUMAR, N.: Vehicular Traffic Noise Modeling Using Artificial Neural Network Approach, Transportation Research Part C: Emerging Technologies, vol. 40, 2014, 111-122, ISSN 0968-090X, DOI: 10.1016/j. trc.2014.01.006.

[18] CAI, M., WANG, H.B., YU, Z., DING, J.L.: Road Traffic Noise Study for a House Community Based on Microscopic Traffic Simulation, Zhendong yu Chongji/J. of Vibration and Shock, vol. 32, No. 24, 2013, 48-55, ISSN 1000-3835.

[19] CHEN, Y. G., YANG, Y. S., JIAN, S. X.: Research of the Spread and Measurement of Urban Traffic Noise, Applied Mechanics and Materials, vol. 684, 2014, 240-244, International Conference on Mechanics and Mechanical Engineering, MME 2014, Wuhan, September 2014, ISSN 1660-9336, DOI: 10.4028/www.scientific.net/AMM.684.240.

[20] METHODICAL INSTRUCTION NO. 77/2011 Establishing the control operations relating to the burden of the environment by the exhaust emissions, sound emissions and radio interference of vehicles performed during the vehicles technical control (Control operations of the group 800 (in Slovak), 2011.

[21] MARisCAL-RAMIREZ, J. A., FERnANDEZ-PRIETO, J. A., CANADA-BAGO, J., GADEO-MARTOS, M. A.: A New Algorithm to Monitor Noise Pollution Adapted to Resource-Constrained Devices, Multimedia Tools and Applications, vol. 74, No. 21, 2015, 9175-9189, ISSN 1380-7501, DOI: 10.1007/s11042-014-2074-3.

[22] LABUDA, R., KOVALCIK, A., REPKA, J., HLAVNA, V.: Simulation of a Wheeled Vehicle Dynamic Regimes in Laboratory Conditions, Communications - Scientific Letters of the University of Zilina, vol. 14, No. 3, 2012, 5-9. ISSN 13354205.

[23] PAllas, M. A., BEREngier, M., CHATAGnON, R., CZUKA, M., CONTER, M., MUIRHEAD, M.: Towards a Model for Electric Vehicle Noise Emission in the European Prediction Method CNOSSOS-EU, Applied Acoustics, vol. 113, 2016, 89-101, ISSN 0003-682X, DOI: 10.1016/j.apacoust.2016.06.012.

[24] TOMASIKOVA, M., LUKAC, M., CABAN, J., BRUMERCIK, F.: Controllability and Stability of a Vehicle, Logi - Scientific J. on Transport and Logistics, vol. 7, No. 1, 2016, 136-142, ISSN 1804-3216.

[25] WEBER, S.: Spatio-temporal Covariation of Urban Particle Number Concentration and Ambient Noise, Atmospheric Environment, vol. 43, No. 34, 2019, 5518-5525, ISSN 1352-2310, DOI: 10.1016/j.atmosenv.2009.06.055.

[26] GNAP, J., KALASOVA, A., GOGOLA, M., ONDRUS, J.: The Centre of Excellence for Transport Service and Control, Communications - Scientific Letters of the University of Zilina, vol. 12, No. 3 A, 2010, 116-120, ISSN 1335-4205.

[27] MARUYAMA, M., KUNO, K., SONE, T.: Minimum Measurement Time Interval to Estimate a Reliable Sound Pressure Level of Road Traffic Noise Using Two Types of Dynamic Statistics, Applied Acoustics, vol. 83, 2014, 150-155, ISSN 0003682X, DOI: 10.1016/j.apacoust.2014.03.007. 